\title{
COMPOSITION OF OVIDUCT FLUID KEPT AT TWO TEMPERATURES DURING COLLECTION FROM SHEEP
}

\author{
D. L. BLACK, A. KUMAR, L. V. GROWLEY,* R. T. DUBY $\dagger$ \\ AND C. H. SPILMAN†
}

Laboratory for Reproductive Physiology, Department of Veterinary and Animal Sciences, University of Massachusetts, Amherst, Massachusetts, U.S.A.

(Received 17th April 1970)

It has never been established that fluid collected from the oviducts of rabbits (Clewe \& Mastroianni, 1960), ewes (Black, Duby \& Riesen, 1963; Restall, 1966; Perkins, Goode, Wilder \& Hensen, 1965; Iritani, Gomes \& VanDemark, 1969), cows (Carlson, Black \& Howe, unpublished data) and monkeys (Mastroianni, Shah \& Abdul-Karim, 1961) is comparable with the fluid normally present in the oviduct. The results of Holmdahl \& Mastroianni (1965) suggest that it may not be comparable since they found that fluid held at low temperatures during collection from rabbits contained more glucose and less calcium than fluid collected at room temperature. A similar experiment was therefore carried out in sheep.

Fourteen ewes of the Dorset and Shropshire breeds were used in the experiment. They were placed in individual stalls, given $1 \mathrm{lb}$ of grain, hay or silage, and unrestricted water. Oestrus was detected with the aid of a ram.

Animals to be cannulated for the collection of oviduct fluid were anaesthetized with Equithesin (Jen-Sal Labs) and the reproductive tract was exposed through a ventral incision anterior to the mammary glands. A silicone rubber (Silastic-Dow Corning) cannula $(0.217 \mathrm{~cm}$ outer diameter, $0.102 \mathrm{~cm}$ inner diameter, $61 \mathrm{~cm}$ long) was inserted through the infundibulum of one oviduct and into the ampulla for about $1 \mathrm{~cm}$. The cannula was retained within the oviduct by two ligatures of synthetic suture material, care being taken not to occlude the lumen. The position and patency of the cannula were determined by forcing a small amount of air into the oviduct. After ligating the uterine end of the cannulated oviduct to prevent passage of oviduct fluid into the uterus, the distal end of the cannula was brought out through the right flank and attached to a plastic test-tube cap which had an opening for air. The cap fitted tightly on the sterile plastic test-tubes in which the oviduct fluid was collected. The wound was closed in the usual manner and the animal allowed to regain full consciousness before being returned to its stall. Each ewe was fitted with a canvas blanket in which there was a pocket in the right side to hold the test-tube and container.

The temperature within the collection vials was controlled by circulating

* Permanent address: Department of Surgery, Albert Einstein College of Medicine, Bronx, N.Y. 10461.

† Permanent address: Department of Animal Science, Cornell University, Ithaca, N.Y. 14850. 
fluid through a double-walled test-tube container made from copper tubing. The container was insulated in polystyrene and the entire apparatus inserted into the pocket in the canvas blanket covering the animal. The temperature was measured with thermocouples and controlled by circulating either alcohol cooled to $-20^{\circ} \mathrm{C}$, or water at $37^{\circ} \mathrm{C}$, through the collection device.

Fluid from the oviducts of one group of seven ewes was held at $-10^{\circ} \mathrm{C}$ or lower during collection ('cold' collection) and that from a second group of

TABLE 1

OVIDUCT SEGRETION IN THE EWE

\begin{tabular}{|c|c|c|c|c|}
\hline \multirow{2}{*}{ Days of sample } & \multicolumn{2}{|c|}{$\begin{array}{l}\text { 'Cold' collection, } \\
(\mathrm{m} / 24 \mathrm{hr})\end{array}$} & \multicolumn{2}{|c|}{$\begin{array}{c}\text { 'Warm' collection } \\
(\mathrm{ml} / 24 \mathrm{hr})\end{array}$} \\
\hline & $\begin{array}{l}\text { No. of } \\
\text { samples }\end{array}$ & Mean $\pm S . D$. & $\begin{array}{l}\text { No. of } \\
\text { samples }\end{array}$ & Mean $\pm S . D$. \\
\hline $\begin{array}{l}6 \text { and } 7 \text { Pro-oestrus } \\
4 \text { and } 5 \text { Pro-oestrus } \\
2 \text { and } 3 \text { Pro-oestrus } \\
\text { Oestrus and } 1 \text { Pro-oestrus } \\
1 \text { and } 2 \text { Postoestrus } \\
3 \text { and } 4 \text { Postoestrus } \\
5 \text { and } 6 \text { Postoestrus }\end{array}$ & $\begin{array}{r}8 \\
10 \\
11 \\
13 \\
13 \\
12 \\
11\end{array}$ & $\begin{array}{l}0.39 \pm 0.32 \\
0.25 \pm 0.18 \\
0.47 \pm 0.36 \\
0.75 \pm 0.40 \\
0.47 \pm 0.25 \\
0.27 \pm 0.23 \\
0.25 \pm 0.20\end{array}$ & $\begin{array}{r}7 \\
6 \\
12 \\
12 \\
16 \\
14 \\
11\end{array}$ & $\begin{array}{l}0.34 \pm 0.30 \\
0.29 \pm 0.15 \\
0.61 \pm 0.52 \\
0.88 \pm 0.51 \\
0.72 \pm 0.46 \\
0.40 \pm 0.33 \\
0.23 \pm 0.27\end{array}$ \\
\hline
\end{tabular}

TABLE 2

CHEMICAL COMPOSITION OF SHEEP OVIDUGT FLUID AND BLOOD SERUM*

\begin{tabular}{|c|c|c|c|c|}
\hline \multirow{2}{*}{ Constituent } & \multicolumn{2}{|c|}{ Oviduct fluid } & \multicolumn{2}{|c|}{ Blood serum } \\
\hline & 'Warm' & 'Cold' & 'Warm' & 'Cold' \\
\hline $\begin{array}{l}\text { Dry matter }(\mathrm{g} / 100 \mathrm{ml}) \\
\text { Calcium }(\mathrm{mg} / 100 \mathrm{ml}) \\
\text { Magnesium }(\mathrm{mg} / 100 \mathrm{ml}) \\
\text { Sodium }(\mathrm{mg} / 100 \mathrm{ml}) \\
\text { Potassium }(\mathrm{mg} / 100 \mathrm{ml}) \\
\text { Chloride }(\mathrm{mg} / 100 \mathrm{ml}) \\
\text { Protein }(\mathrm{g} / 100 \mathrm{ml}) \\
\text { Glucose }(\mathrm{mg} / 100 \mathrm{ml})\end{array}$ & $\begin{array}{c}2 \cdot 66 \pm 0.90 \\
3 \cdot 97 \pm 0.33 \\
1.20 \pm 0.07 \\
264.43 \pm 18 \cdot 00 \\
31 \cdot 28 \pm 2 \cdot 25 \\
570.86 \pm 72 \cdot 12 \\
1.94 \pm 0.65 \\
1.37 \pm 0.24\end{array}$ & $\begin{array}{c}2 \cdot 72 \pm 0.71 \\
4 \cdot 02 \pm 0.45 \\
1 \cdot 22 \pm 0 \cdot 10 \\
235 \cdot 00 \pm 8 \cdot 29 \\
28 \cdot 09 \pm 1 \cdot 66 \\
422 \cdot 83 \pm 65 \cdot 23 \\
1 \cdot 66 \pm 0.56 \\
1 \cdot 07 \pm 0.25\end{array}$ & $\begin{array}{c}8 \cdot 86 \pm 0 \cdot 40 \\
12 \cdot 48 \pm 0 \cdot 35 \\
2 \cdot 11 \pm 0 \cdot 14 \\
221 \cdot 71 \pm 2 \cdot 90 \\
30 \cdot 93 \pm 1 \cdot 58 \\
393 \cdot 49 \pm 34 \cdot 04 \\
6.92 \pm 0 \cdot 41 \\
\text { Not determined }\end{array}$ & $\begin{array}{c}9 \cdot 08 \pm 0 \cdot 45 \\
11 \cdot 86 \pm 0 \cdot 99 \\
2 \cdot 04 \pm 0 \cdot 14 \\
207 \cdot 86 \pm 11 \cdot 32 \\
27 \cdot 14 \pm 3 \cdot 88 \\
392 \cdot 75 \pm 30 \cdot 94 \\
6 \cdot 81 \pm 0 \cdot 84 \\
\text { Not determined }\end{array}$ \\
\hline
\end{tabular}

* Average of all samples collected during periods listed in Table 1.

seven ewes was held at $25^{\circ}$ to $40^{\circ} \mathrm{C}$ ('warm' collection) under aseptic conditions. The samples were placed on ice until they reached the laboratory ( 30 min) and kept frozen until they were analysed.

Dry matter was determined by placing $200 \mu \mathrm{l}$ of oviduct fluid on pre-weighed aluminum planchets with a microlitre pipette. The pipette was washed twice with doubly distilled water and the washings were added to the planchet. The samples were dried at $65^{\circ} \mathrm{C}$ for $48 \mathrm{hr}$, transferred to a desiccator, and allowed to cool before weighing.

Sodium, potassium, calcium and magnesium were analysed by atomic absorption spectrophotometry. Chloride was determined by the mercuric chloranilate method of Barney \& Bertolacini (1957) and Hodge \& Gerarde 
(1963). Protein was determined by the biuret method of Kingsley (1939) and glucose was determined enzymatically (Bergmeyer, 1963).

The effect of oviduct fluid on the oxygen uptake by spermatozoa was measured as previously described (Black, Crowley, Duby \& Spilman, 1968).

There were no significant differences between the two groups of ewes in the rates of secretion of fluid by the oviduct. Both groups showed the highest rate of secretion at oestrus and the lowest at 5 to 6 days after oestrus (Table 1), as had been previously observed by Black et al. (1968). The composition of the fluid was not affected by keeping it cold during collection (Table 2) and the values were similar to those already reported for dry matter (Iritani et al., 1969) and magnesium, potassium and chloride (Restall \& Wales, 1966) in the ewe. Our values were lower than those previously reported for protein (Restall \& Wales, 1966) and glucose (Iritani et al., 1969).

TABLE 3

EFFECT OF OVIDUCT FLUID ON RESPIRATION OF RAM SPERMATOZOA

\begin{tabular}{|c|c|c|c|c|}
\hline \multirow{3}{*}{ Days sample pooled } & \multicolumn{4}{|c|}{$\begin{array}{l}\text { Percentage increase }(+) \text { or decrease }(-) \text { of oxygen } \\
\text { consumption of spermatozoa in oviduct fluid }\end{array}$} \\
\hline & \multicolumn{2}{|c|}{$\begin{array}{l}\text { 'Warm' } \\
\text { collection }\end{array}$} & \multicolumn{2}{|c|}{$\begin{array}{l}\text { 'Cold' } \\
\text { collection }\end{array}$} \\
\hline & $\begin{array}{c}1 s t h r \\
(\%)\end{array}$ & $\begin{array}{c}2 n d h r \\
(\%)\end{array}$ & $\begin{array}{l}1 s t h r \\
(\%)\end{array}$ & $\begin{array}{c}2 n d h r \\
(\%)\end{array}$ \\
\hline $\begin{array}{l}6 \text { and } 7 \text { Pro-oestrus } \\
4 \text { and } 5 \text { Pro-oestrus } \\
2 \text { and } 3 \text { Pro-oestrus } \\
\text { Oestrus and } 1 \text { pro-oestrus } \\
1 \text { and } 2 \text { Postoestrus } \\
3 \text { and } 4 \text { Postoestrus } \\
5 \text { and } 6 \text { Postoestrus }\end{array}$ & $\begin{array}{r}+106 \cdot 43 \\
+150 \cdot 60 \\
+75 \cdot 23 \\
+24 \cdot 78 \\
+42 \cdot 26 \\
+52 \cdot 97 \\
+92 \cdot 60\end{array}$ & $\begin{array}{r}+7 \cdot 41 \\
+23 \cdot 21 \\
+11 \cdot 21 \\
+9 \cdot 08 \\
+37 \cdot 26 \\
+47 \cdot 97 \\
+18.48\end{array}$ & $\begin{array}{r}+89.03 \\
+115.66 \\
+91.17 \\
-0.77 \\
+41.09 \\
+40.47 \\
+23.19\end{array}$ & $\begin{array}{l}+18.41 \\
+33.85 \\
+26.20 \\
+26.92 \\
+44.71 \\
+35.47 \\
+28.19\end{array}$ \\
\hline
\end{tabular}

Values in the ewe for blood serum composition (Table 2) were similar to those reported for calcium, magnesium, chloride and protein but higher for potassium and glucose (Restall \& Wales, 1966).

Although oviduct fluid generally increased sperm respiration (Table 3), the 'cold' sample collected on the day of pro-oestrus plus the day of oestrus caused practically no increase in the respiration of spermatozoa during the $1 \mathrm{st} \mathrm{hr}$ and then decreased oxygen consumption by $27 \%$ during the $2 \mathrm{nd}$ hr of incubation. With the corresponding 'warm' sample, there was little increase in oxygen consumption during the $1 \mathrm{st} \mathrm{hr}$ of incubation but it increased slightly during the $2 \mathrm{nd} \mathrm{hr}$ of incubation. These data are different from those reported earlier (Black et al., 1968).

In general, data on the chemical composition of oviduct fluid and blood serum obtained in this study agree well with those obtained by other workers. The discrepancies which were observed may have resulted from different nutritional and environmental conditions. The important fact is that there were no changes evident in the concentrations of substances measured in oviduct fluid collected at the two different temperatures. The possibility remains that oviduct fluid 
may change chemically before it enters the collection device. The cannula from the oviduct to the collection device in the sheep, unlike that in the rabbit, must be long to accommodate the size of the animal. Since the volume of fluid produced is essentially the same in the two animals, the time required for passage through the cannula is increased and, during this interval, chemical change may occur.

\section{REFERENCES}

Barney, J. E., II \& Bertolacini, R. J. (1957) Colorimetric determination of chloride with mercuric chloranilate. Anal. Chem. 29, 1187.

Bergmeyer, H. U. (1963) Methods of enzymatic analysis. Academic Press, New York.

Black, D. L., Crowley, L. V., Duby, R. T. \& Spilman, C. H. (1968) Oviduct secretion in the ewe and the effect of oviduct fluid on oxygen uptake by ram spermatozoa. F. Reprod. Fert. 15, 127.

BlAck, D. L., Duby, R. T. \& RIESEN, J. (1963) Apparatus for the continuous collection of sheep oviduct fluid. F. Reprod. Fert. 6, 257.

Clewe, T. W. \& MAstroianNi, L., JR (1960) A method for continuous volumetric collection of oviduct secretion. F. Reprod. Fert. 1, 146.

Hodge, G. J., JR \& Gerarde, H. W. (1963) A micro-colorimeter method for the determination of chloride. Microchem. 7. 7, 326.

HolmdahL, T. H. \& MASTROIANNI, L., JR (1965) The continuous collection of rabbit oviduct secretion at low temperature. Fert. Steril. 16, 587.

Iritani, A., Gomes, W. R. \& VANDEmark, N. L. (1969) Secretion rates and chemical composition of oviduct and uterine fluids in ewes. Biol. Reprod. $1,72$.

KINGSLEY, G. R. (1939) The determination of serum total protein, albumin, and globulin by the biuret reaction. F. biol. Chem. 131, 197.

Mastroianni, L., JR, Shah, U. \& Abdul-Karim, R. (1961) Prolonged volumetric collection of oviduct fluid in the rhesus monkey. Fert. Steril. 12, 417.

Perkins, J. L., Goode, L., Wilder, W. A., Jr \& Henson, D. B. (1965) Gollection of secretions from the oviducts and uterus of the ewe. F. Anim. Sci. 24, 383.

Restali, B. J. (1966) The Fallopian tube of the sheep. I. Cannulation of the Fallopian tube. Aust. $\mathcal{F}$. biol. Sci. 19, 101.

Restall, B. J. \& Wales, R. G. (1966) The Fallopian tube of the sheep. III. The chemical composition of the fluid from the Fallopian tube. Aust. F. biol. Sci. 19, 687. 